\title{
Hybrids by Choice or by Chance: Applying Hybrid Spectrum Typology in Croatian Tourism
}

\author{
Jelena Đurkin Badurina \\ University of Rijeka, Faculty of Tourism and Hospitality Management, Opatija, Croatia \\ Marko Perić \\ University of Rijeka, Faculty of Tourism and Hospitality Management, Opatija, Croatia \\ Jelena Kljaić Šebrek \\ WYG Consulting Ltd, Zagreb, Croatia
}

\begin{abstract}
This paper analyses the concepts of hybridity and hybrid spectrum organizations as important phenomena in the modern world. To improve the understanding of this concept, main characteristics of hybrid organizations are listed and discussed, with emphasis on typology of the hybrid spectrum. In order not to stop at a mere theoretical review, the purpose of this paper is to analyze specific characteristics of organizational hybrids in the field of tourism and to discuss the influence of some external environmental determinants (e.g. level of tourism development and the context of national legislation) on the motivation and mission of hybrid organizations. Croatia has been chosen as a study area, being one of the most popular tourist destinations in Europe, as well as an example of an economy that is heavily dependent on tourism. The results of the discussion provide arguments in favor of adopting a hybrid approach for sustainable tourism development. The selected examples from Croatia underline the necessity of introducing more sustainable business models in this financially lucrative sector, but also emphasize the key role of specific contextual circumstances in forming and developing hybrid organizations.
\end{abstract}

\section{Keywords}

Hybrid organizations, hybrid spectrum, tourism, sustainability.

\section{Introduction}

Hybridity as a phenomenon is discussed in contemporary literature and practice from various perspectives. Since the term itself originates from nature, more specifically from hybrid species, the general notion of hybridity encompasses a combination of elements that have usually been perceived as separate from one another (Schmitz \&Glanzel, 2016). The concept has a wide usage in technology, the IT sector, business management and organizational studies. The latter represents the framework through which hybridity will be examined in this paper.

There is no generally accepted definition of hybrid organizations, because there are various research streams with different points of focus.
The perspective of special interest for this paper perceives hybrid organizations as a combination of economic and social features, or as defined by Cooney "organizations that combine business enterprises with a social purpose mission" (Cooney, 2006, p. 145). This type of hybrid organization is growing in numbers and strength (Alberti\&VaronGarrido, 2017). Moreover, some authors argue that the hybridization process, as the development of sustainable solutions to different problems through innovative business models, offers a promising vehicle for the creation of both social and economic value and represents an early step in a broad reformulation of the current economic order (Battilana, Lee, Walker, \& Dorsey, 2012). To better understand this concept and facilitate 
strategic management and planning for the further development of hybrids, existing research still requires more discussion on the common identifying characteristics of hybrid organizations and their activities, mission and contribution through the lenses of particular sectors. Hence the purpose of this paper is to identify and analyze specific characteristics of organizational hybrids in the field of tourism and to discuss the influence of some external environment determinants (e.g. level of tourism development and the context of national legislation) on motivation, mission and the overall social and economic impacts of hybrid organizations.

For establishing a theoretical framework in the first part of this paper, the approach of hybrid organizations as a vast continuum between completely non-profit features and exclusively commercial features (Dees, 1998; Dees \& Anderson, 2003 ) is adopted and simplified by using the hybrid spectrum typology developed by Sutia Kim Alter (Alter, 2007). The types of organizations within the hybrid spectrum typology are then discussed in terms of the tourism sector of Croatia in the second part of the paper. Croatia was chosen as one of the most popular tourist destinations in Europe, as well as an example of an economy that is heavily dependent on tourism. The specific conditions in a particular sector and national legislation enables discussion on hybrids not just as "idealistic" organizations created by inspired philanthropic entrepreneurs, but also as phenomenon rooted in specific legal and sectoral contexts. Through the discussion on several specific examples of hybrids from Croatian tourism practice, the importance of the legal context in terms of constraints as well as opportunities is emphasized in order to compare hybrid organizing by choice with organizing by chance.

\section{Short overview of hybrid organizations and the hybrid spectrum}

The complexity of the concept of hybridity in the field of business and organizational studies is visible in the many attempts to define it. According to Grassl's systematization of literature, hybrids can be identified by various criteria of classification, based on the elements they are combining (Grassl, 2012):

1. by ultimate ends: for-profit vs. non-profit

2. by societal sector: market vs. civil society vs. state
3. by type of integration: external vs. integrated vs. embedded

4. by goods produced: private vs. public

5 . by product status: goods vs. services

6 . by agents of value creation: producers vs. consumers

7. by ownership (corporate governance): private vs. cooperative vs. public

The main focus of this paper is on "sustainability-driven" organizations which combine businesses' industrial and innovation strengths to become economically potent entities, but also address specific social and environmental issues and perform the following activities: (1) drive a positive social/environmental change as an organizational objective, (2) create mutually beneficial relationships with stakeholders and (3) interact progressively with the market, competitors, and industrial institutions (Haigh \& Hoffman, 2012).

Since non-profit vs. for-profit and economic vs. social are the most important dichotomies for our approach, the hybrid spectrum typology developed by Kim Alter will be used as the key model for understanding the types of hybrid organizations in the context of their motives, accountability and profit orientation/use of income.

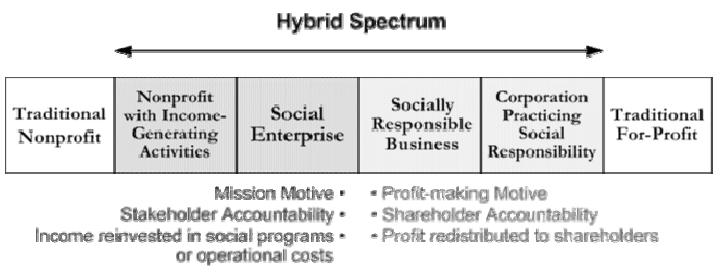

Figure 1 Hybrid spectrum Source: Alter, 2007, p. 14

Figure 1 represents the model with two main groups of organizations: profit driven organizations on the right, which include socially responsible businesses and corporations practicing social responsibility, and mission-driven organizations on the left, comprised of social enterprises and non-profits with income-generating activities. Organizations on the left side are usually funded with the purpose of creating social value and their financial sustainability is ensured through fundraising, but also by market-oriented activities (especially in the case of social enterprises). On the right, the "for-profit" part of the spectrum includes organizations with more entrepreneurial characteristics which cater to interests of owners/stakeholders, but still differ from "classic" forprofit companies in terms of strong social pro- 
grams and even find the social outcomes of their activities equally important as financial sustainability (the case of socially responsible businesses).

As the author of the hybrid spectrum typology, Alter describes the main four types of hybrid organizations in more detail as follows (Alter, 2007):

1. Non-profits with income-generating activities: non-profit organizations that incorporate some form of revenue generation through commercial means into their operations. Usually those income-generating activities are not conducted as a separate business, but are rather integrated into the organization's activities. Usually revenue from such activities is relatively small compared to traditional fundraising contributions

2. Social enterprises: organizations operating as businesses with market activities, but with the motive/mission to create a specific social value. The purpose of the entrepreneurial approach may be an additional funding mechanism for the organization's social programs or operating costs, a sustainable mechanism in support of the organization's mission or a leadership development mechanism in support of social innovation. Business success and the social impact of social enterprises are interdependent and their activities are usually managed and/or overviewed by qualified staff with experience in business or industry.

3. Socially Responsible Businesses: For-profit companies that operate with dual objectives: making profit for their shareholders and contributing to a broader social good. In socially responsible businesses the degree to which profit-making motives affect decisions and the amount of profit designated for social activities differs. Socially responsible businesses are willing to forsake profit or make substantial financial contributions rather than distribute earnings privately, and frequently place social goals in their corporate mission statements. In some cases, a socially responsible business may be considered a social enterprise when it is a registered for-profit subsidiary owned by a non-profit organization (parent organization) created for the purpose of earning income for the parent organization as well as supporting a social cause.
4. Corporations practicing social responsibility: for-profit businesses whose motives are financially driven, but which engage in philanthropy. This type of "strategic philanthropy" helps companies achieve profit maximization and market share objectives while contributing to public good. Private companies or corporations can engage in socially beneficial activities such as grants, community involvement, volunteering company personnel and sponsorships as a means to improve public image, employee satisfaction, sales and customer loyalty. Therefore, even though these philanthropic activities may support social enterprises, make a positive social impact, or contribute significantly to public good, corporate social responsibility is not classified as a socially responsible business or social enterprise.

The described typology distinguishes between four types of hybrid organizations along the nonprofit - for-profit continuum, but, due to the high level of abstraction, does not provide information regarding particular organizational structures and types of activities. According to Mair and Marti, the choice of set-up of hybrid organizations is typically dictated by the nature of the social needs addressed, the amount of resources needed, the scope for raising capital, and the ability to capture economic value (Mair\& Marti, 2006). In the next chapter, the authors analyze the sometimes blurred boundaries between the types of hybrid organizations by applying the hybrid spectrum typology in a specific sector and national context.

\section{Applying the hybrid spectrum typology in the field of tourism}

Tourism was chosen for discussion and application of the hybrid spectrum as an extremely propulsive phenomenon with complex economic and social impacts. On the global level, reaching a total of 1,322 million, international tourist arrivals grew by a remarkable $7 \%$ in 2017 , which is well above the sustained and consistent trend of $4 \%$ of average growth since 2010 and represents the strongest results in seven years (UNWTO, 2018). According to the same source, Europe achieved respectably $8 \%$ more international arrivals than in 2016, and the most successful were Mediterranean destinations. 
Croatia has been chosen for the study area as a very popular tourist destination with constant growth in tourism figures. In 2017, there were 17.4 million tourist arrivals and 86.2 million tourist overnight stays recorded in tourist accommodation establishments in Croatia, so compared to 2016 , arrivals increased by $13 \%$ and overnight stays by $11 \%$ (Croatian Bureau of Statistics, 20187). What sheds additional light on the importance of tourism for the Croatian economy is the fact that the contribution of tourism to the gross domestic product was a little bit over $18 \%$ in 2017, which is among the highest in Europe. This underlines the need for research of tourism enterprises from various perspectives, including their potentials to achieve social along with economic goals. The tourism context generally offers many opportunities for the development of sustainable products and services, from green tourism solutions as environmentally friendly innovations in the touristic offer (Gavrilović\&Maksimović, 2018) to social tourism as a potentially valuable solution for the participation of socially disadvantaged groups in tourism/holidays (Minnaert, Maitland, \& Miller, 2011).

Still, the main building blocks of sustainable tourism development are organizations/enterprises working in the field of tourism, and they are being shaped under the influence of particular national contexts and available resources. Therefore, the previously described types of hybrid organizations will be discussed through the theoretical analysis of Croatian tourism-oriented organizations.

\subsection{Non-profits with income-generating activities in Croatian tourism}

This research identified two examples within this type: tourist boards as public sector non-profit organizations with the possibility to generate income from the market, and associations generating income directly or indirectly from tourism.

\subsubsection{Tourist boards}

Tourist boards are non-profit entities and the only legally defined public support elements of the tourism management system in Croatia. They are mostly oriented on destination marketing and to a very limited extent, to product management. There are over 280 local tourist boards and 21 regional tourist boards - one per each county (Croatian National Tourist Board, 2018). The Tourism Development Strategy of the Republic of Croatia until 2020 analyzed that system and identified that a significant number of local tourist boards have limited material and human resources, low functional activity, and that decisions are mostly made based on individual positions of local, municipal or regional authorities, or influenced by various interest groups (Institute for Tourism, 2013). The Law on Tourism Boards allows tourist boards of local and regional level to generate additional income from the following activities: managing public tourism infrastructure, selling souvenirs and local products, organizing events and even mediating in booking accommodation, but only if there is no registered tourist agency in that area, according to Law on Tourism Boards (Croatian Parliament, 2008). Performing those activities makes tourist boards potential hybrid organizations, but previous research on that topic confirmed that most of the tourist board directors prefer to transfer all profit-related activities to the private sector through various concession contracts and public-private partnerships rather than take the responsibility and associated risks related to market activities (Mandić, Mrnjavac, \&Kordić, 2018).

However, according to the Tourism Development Strategy "When it comes to the rationalization of the system, merging of certain local tourist boards is encouraged, following the principles of spatial, functional and manufacturing integrity... Along with ensuring complete coverage of the territory of the Republic of Croatia, merger of tourist boards in certain areas, and consequently the responsibility for work in destination management, is generally based on financial selfsufficiency criteria" (Institute for tourism, 2013, p. 59). This recommendation might motivate some tourist boards to engage in market activities in order to ensure additional income, but defining mechanisms to be economically active, without creating unfair competition for the local private sector will be a very challenging task.

On the other hand, many tourist boards in the continental part of Croatia which are situated in under-developed regions do not have a sufficiently strong tourist offer or private sector initiative. For them, supporting tourism development means taking more initiative in market-oriented tourism activities, especially in public tourism infrastructure management, since attractions are the main motive for tourists to visit a certain area. In rural areas without a strong tourism tradition and renowned tourist attractions, local tourist boards can become generators of local tourism development and create sustainable tourist products with significant emphasis on environmental preservation and 
social benefits for the residents of those communities (Đurkin\&Wise, 2017). Therefore, for survival of such tourist boards, it is essential to engage in income-generating activities.

\subsubsection{Income-generating associations active in Croatian tourism}

According to the Croatian Law on Associations, "Association is any form of free and voluntary association of natural or legal persons who, in order to protect their interests or to promote the protection of human rights and freedoms, environmental protection and sustainable development, humanitarian, social, cultural, educational, scientific, sports, healthcare, technical, information, professional or other beliefs and goals that are not contrary to the Constitution and law, without the intention of making profit or other economically estimable benefit, submit themselves to the rules that regulate the organization and activities of this form of association." (Croatian Parliament, 2014). The same law allows associations to perform an economic activity in accordance with the law and their statute, but those activities must not be performed in order to make a profit for the association's members or third persons. If, during the performance of economic activities, an association has made a surplus of receipts over expenses, such a surplus shall be used, in line with the statute of the association, exclusively to fulfill the goals defined by the statute (Croatian Parliament, 2014).

According to the Register of Associations of the Republic of Croatia there are nearly 53,000 active associations operating in the fields of democratic political culture, spirituality, economy, hobbies, the Homeland War, art and culture, human rights, international cooperation, sport, education, science and research, sustainable development, social system and other (Ministry of Public Administration, 2018). In the thematic area of economy, there is a subsection of tourism, but only 593 associations listed it as one of their activities. However, this information should be carefully evaluated, since many associations in the field of sport, art, culture, and other fields, do not list tourism as a main activity, but do sell their products to tourists during various fairs, and organize events which become an important part of the tourist offer.

By selling products and services to tourists and visitors, tickets for events and festivals, and fees for participating in sport events in particular destinations, those associations achieve additional income from tourism. Growth in the number of tourist arrivals, trends on the tourism market, motivation and special interests of tourists are important factors for those associations capable of producing services, products and overall experiences to satisfy tourists' expectations. Also, due to the clear restriction in the Law on Associations, surpluses generated by associations' economic activities must be used to fulfill (usually social) objectives of associations, which automatically reduces the pressure on public budgets for funding those non-profits.

One example of an association highly engaged in providing tourist offer is Istra Inspirit, which gathers individuals related to culture, visual arts, performing and acting. One of their most prominent activities is the creation and delivery of interactive visual events based on heritage, history and legends of particular places in the region of Istria (Western Croatia) and these events are mostly oriented towards tourists and visitors with the aim to provide a unique experience (Istra Inspirit Association, 2018). Performances and shows on specific historical topics (including costumes, special effects and acting prompts), so called "living history", are the main outputs of the Istra Inspirit association, while catering, transportation and other logistic issues are the responsibilities of each local event organizer (usually tourist boards). Apart from creating 12 "Istra Inspirit" events from spring to autumn that successfully combine history, art, live performances and gastronomy in a unique experience, the association offers specialized programs for children as well as custom MICE events for the business sector with the possibility of a multilingual performance (Istra Inspirit Association, 2018). Even though this is an outstanding example of a creative cultural tourism project with a promising future, it is important to note that this association is significantly supported by regional authorities and public sector institutions, and that the very idea of Istra Inspirit events was created by the Istrian county, Istrian Development Agency and Istrian Tourism board as a public project (Perić, Đurkin, \&Lamot, 20143). Therefore, the sustainability of this association does not depend just on self-sufficiency because a large portion of the marketing costs, the online ticketing system, as well as initial investment in equipment and costumes are covered by public sector funding. Although this brand is, without any doubt, worth the support, the competitive advantage this particular association gains from continuous public support might seem unfair com- 
pared to other associations in the same field which do not have this type of support.

A much more drastic example of seizing the favorable opportunities as an impulse for lucrative financial activities is the association "Society of Friends of Dubrovnik Antiques", which has existed in Dubrovnik for over 60 years. Due to the specific long-term agreement with the City of Dubrovnik, this association is in charge of the maintenance and management of the city walls of Dubrovnik and walls of Ston - two significant cultural monuments that attract hundreds of thousands of visitors every year. Even though $50 \%$ of the income from the tickets for the city walls of Dubrovnik is transferred to local self-government, the remaining income surpasses the financial responsibilities related to wall preservation, and represents an abundant source for funding additional activities of this association, oriented towards culture and art.

Table 1 Summary of a financial report of the Society of Friends of Dubrovnik Antiques for 2016

\begin{tabular}{l|r}
\hline \multicolumn{1}{c|}{ REVENUE } & $\begin{array}{c}\text { EUR } \\
\text { (exchange rate from } \\
\text { 2016) }\end{array}$ \\
\hline $\begin{array}{l}\text { Tickets for the city walls of } \\
\text { Dubrovnik (50\%) }\end{array}$ & 5702388,88 \\
\hline Tickets for Ston walls & 188571,27 \\
\hline Other tickets & 39105,31 \\
\hline Dubrovnik city card & 395709,90 \\
\hline Renting space & 120678,08 \\
\hline Membership fees & 543,88 \\
\hline Interests & 68620,46 \\
\hline Other income & 1446,95 \\
\hline TOTAL REVENUE & 6517064,73 \\
\hline EXPENSES & 4130113,44 \\
\hline Maintenance of monuments & 160528,76 \\
\hline $\begin{array}{l}\text { Donations and support from other } \\
\text { institutions/programmes in the field } \\
\text { of art and culture }\end{array}$ & \\
\hline $\begin{array}{l}\text { Indirect costs (including } \\
\text { representation, promotion, per } \\
\text { diems, IT support, etc.) }\end{array}$ & 545535,56 \\
\hline $\begin{array}{l}\text { Salaries, wages, student contracts, } \\
\text { author's contracts, etc. }\end{array}$ & 1019316,68 \\
\hline TOTAL EXPENSES & 5855494,44 \\
\hline NET INCOME & 661570,29 \\
\hline
\end{tabular}

Source: summarized data from the Society of Friends of Dubrovnik Antiques, 2017

The financial report for 2016 reveals the enormous financial strength of this association compared to other Croatian non-profits. The nonprofit principle has been respected in terms of expenditures on activities which are closely related to the core goals of the association. The sur- plus at the end of 2016 was transferred to the next year.

The popularity of Dubrovnik as a destination and the city walls as one its key landmarks ensures a financially prosperous future for the Society of Friends of Dubrovnik Antiques, but there will probably be much discussion centered on the suitability of this management model, as well as the size and impact of the benefits for the community that accrue from it.

\subsection{Social enterprises in Croatian tourism}

Even though social enterprises are the most prominent representatives of hybrid organizations, this concept is still rather underdeveloped in Croatia. There is no specific law on social entrepreneurship, but in 2015, the "Strategy for the Development of Social Entrepreneurship in the Republic of Croatia for the period 2015-2020" was adopted. It represents a key document for the creation of a policy framework for social enterprises with the main objective to boost the creation and growth of social enterprise in Croatia by establishing a more supportive institutional and financial environment. The Strategy defines social enterprises as "businesses based on the principles of social, environmental and economic sustainability, where profit/surplus is, wholly or in great part, reinvested for the community benefit" (Government of the Republic of Croatia, 2015). Social enterprises in Croatia can take any legal form and there are nine criteria to identify as / be considered a social enterprise (Government of the Republic of Croatia, 2015):

1. set balanced social, environmental and economic goals

2. produce goods and/or deliver services, or generate revenue on the market, with a favorable impact on the environment and society

3. generate at least $25 \%$ of their annual income from their entrepreneurial activities, based on a three-year operating or planning period

4. invest at least $75 \%$ of their profit/surplus in their activities and/or objectives

5. offer voluntary and open membership, and business autonomy

6. not be founded solely by the Republic of Croatia, a local/regional self-government, or a public authority

7. apply rules of democratic governance, where decision-making includes relevant 
stakeholders in addition to shareholders or members

8. monitor and evaluate their social, economic and environmental impact

9. transfer assets to another social enterprise, or a local and regional authority, in case of termination (asset lock)

Many of these criteria are understandable, but too wide and hard to operationalize and measure (especially in the very first years of the organization's existence). Also, as noticed by some researchers, without proper laws, new legal forms and special benefits designed to support the development of social enterprises, the Strategy and listed criteria remain merely a general orientation instead of a strategic tool (Šimleša, Bušljeta Tonković, \&Puđak, 2016).

Maybe the most familiar legal form of social entrepreneurship existing in Croatia for the last 5 years are social cooperatives. Compared to traditional cooperatives, the main difference that social cooperatives bring to their mission is that they are not focused on the interest of their members or owners, but on the welfare of society or the community as a whole, or in particular on the needs of specific, vulnerable, or most fragile social groups (Defourny\&Nayssens, 2013). In Croatia, social cooperatives comprise a small portion of the cooperative sector: with 49 entities (in 2016), they constitute only around $3.8 \%$ of the total number of cooperatives and half of them do not have a single employee (Vidović\&Rakin, 20176). Croatian social cooperatives, even though oriented on the service sector, do not engage in the tourism sector (exploring reasons why might be a topic for a new piece of research), and many of them are initially created to seize favorable conditions and financial benefits from various public programs (e.g. veteran cooperatives). Therefore, as an example of a social enterprise in the field of tourism we take a look at Hedona Ltd as one of the rare enterprises that fulfils all of the criteria listed in the "Strategy for the Development of Social Entrepreneurship in the Republic of Croatia for the period 2015$2020 "$ ".

Hedona Ltd Chocolaterie was founded in 2013 with the aim of providing work primarily for the disabled. It was founded by the Association of Disabled People Križevci and the main activity of the company is the production of chocolate and chocolate pralines (Hedona, 2018). According to the enterprises' founders, all the profits are reinvested back into the employees; into growing their competences and their satisfaction and also into new job opportunities and the company's technological development, as well as the expansion of the company's activities. Chocolates, pralines and specific packaging with local motives, suitable for tourist souvenirs are available through their online web shop, as well as in a few shops in the region. From 6 employees in 2015, the enterprise grew to 18 employees in 2018, due to the new project: opening of the "Choco bar by Hedona" in Križevci. Although this enterprise is not directly oriented towards tourists, the innovative packaging and choco bar can be interesting elements of the tourist offer, appealing to foreign visitors to Križevci. Therefore, Hedona Ltd. is slowly exploiting vast potentials that the tourism sector offers. A small but symbolically significant portion of the 1.6 million investment in the "choco bar" was gathered through a crowdfunding campaign, which also contributed to the overall visibility of the enterprise and its social orientation. At the same time, the association that founded Hedona Ltd. is in constant search of donations, grants or other sources of funding to ensure the financing of new machinery and equipment to expand the production and employ new people. In the first two months from opening, the choco bar has had a significant number of clients. However, according to the profit and loss statement for Hedona Ltd, publicly available on the Annual Financial Reports Registry (Financial agency, 2018), the enterprise ended 2017 with a net loss of 14.016 EUR. This loss can be attributed to starting up a new and demanding investment project. Creating and orienting more products and services on tourists and visitors to Križevci, but also producing souvenirs for a larger market could increase sales and enable a financially more self-sustainable future for this social enterprise.

\subsection{Socially responsible businesses in Croatian tourism}

With respect to the thin line between a social enterprise and socially responsible business (shift towards profit-driven organizations), the authors will provide an example of a unique and innovative socially responsible business in Croatian tourism. It is Mon Perin Ltd., a successful tourism enterprise founded in Bale (Istria) with a unique ownership structure and strong local community commitment. This enterprise was founded as an innovative solution to the slow and unsustainable development of the municipality of Bale and inefficient management of its tourist attractions - 
mainly two camps that were the property of municipality and under concession.

The idea behind founding Mon Perin Ltd. was to manage local tourism development in an entrepreneurial manner with including members of the local community.

From the beginning, the company had three categories of founders (Mon Perin, 2018a):

1. Locals as founders: the citizens of Bale who had the right to become partners in the Mon Perin company by making a deposit

2. Non-residents as founders: interested investors not conditioned by permanent residency in the municipality

3. Municipality as a founder: the Municipality of Bale also contributed to the founding of the company

The distinguishing characteristics of the social contract which was concluded with the establishment of Mon Perin consisted in the fact that, regardless of the distribution of shares, the categories of founders had different voting rights in decision making: the local founders and the municipality as a founder jointly hold 51 per cent of the votes, to ensure that the interests of the local community are put ahead of the interests of investors (Perić\&Đurkin, 2014). Getting concession over the two camps was the first business decision of Mon Perin Ltd in 2005 and after an extensive investment cycle, those camps tripled the number of overnight stays. Throughout the last 10 years, the company has successfully retained this specific model of ownership and decision making, and every year invested the majority of the net income in the improvement of the quality of camps, opening new facilities, as well as community projects such as a spatial planning development study of the entire municipality with special emphasis on sustainable development and carrying capacity of the area (Mon Perin, 2018b).

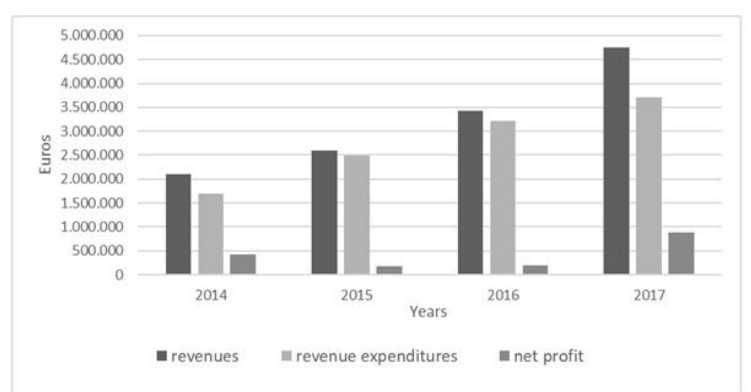

Figure 2 Overview of business income, business expenses and net profit from 2014 to 2017 Source: Adapted from Mon Perin, 2018b
Figure 2 provides evidence on successful management of Mon Perin Ltd. The average yearly net profit of the company for the last four years is around 400000 EUR, while the number of employees (mostly local people) is currently around 110 during high season. Although the profit rate is not increasing exponentially, the important impact of expenditures on quality improvements, aboveaverage salaries, environmental safety, development plans, etc. is visible not just through creating a recognizable destination, but also in the overall improvement of the standard of life of the residents of Bale. The municipality has doubled its budget compared to the period before establishing Mon Perin and the main income sources are land lease for camps (almost $20 \%$ of the entire budget), income tax and for local tourist board - the tourist tax (Perić\&Đurkin, 2014). New income enabled a decrease in the surtax rate for residents, and the Municipality of Bale increased its number of residents by 5\% from 2001 to 2011 (Croatian Bureau of Statistics, 2011).

One of the most ambitious future plans of the company is to transform the old part of Bale into a unique town-hotel (diffuse hotel), first of that kind in Croatia, and to involve the entire community in its management and running.

Innovatively combining profit-making from tourism development with socio-economic development of the local community can obviously be successful, but only in very particular contextual situations. The example of Mon Perin has been researched and presented as a best practice example in different parts of Croatia, but, so far, no enterprise like it was yet created. Favorable initial cooperation between Mon Perin and the local municipality, as well as the convenient existence of tourist infrastructure owned by local government (in case of Mon Perin it was land where camps were situated), are hard to replicate in a different environment. Still, the success of Mon Perin lights a beacon of hope for the future development of similar initiatives, but also evokes active change in local organizing practices and attitudes towards tourism.

\subsection{Corporations practicing social responsibility in Croatian tourism}

When we switch our analysis from the mission driven part of the hybrid spectrum to organizations that are motivated by profit, it is important to describe LOHAS as potential motivation for for-profits to engage in socially and environmentally responsible activities. LOHAS (Lifestyles of 
Health and Sustainability) is a market segment comprising individuals and businesses focused on the environment, a healthy lifestyle, sustainable living and social justice (Gill, 2014). The value of the LOHAS market in the USA alone was estimated at $\$ 209$ billion in 2008, and by 2011 it had grown to $\$ 290$ billion (Haigh \& Hoffman, 2012). Even though this market is limited to a few developed countries, the trend itself (especially in tourism) has given rise to corporate social responsibility as a potential source of positive differentiation and competitive advantage (Dwyer, Ateljević, \&Tomljenović, 2017).

In line with that, many companies providing a tourist offer in Croatia are continuously adding new socially and environmentally responsible practices into their business and use it in promotional materials and campaigns (Slivar\&Golja, 2015).

For instance, hotels and restaurants buying from local suppliers, especially producers of organic or eco food can be considered as enterprises that practice social and environmental responsibility. On the other hand, this cooperation also increases the quality of the tourist offer and can be used in promotion as leverage in terms of attracting LOHAS and other market segments interested in local ingredients and gastronomy. There are several eco certificates that can be awarded to Croatian hotels, but high seasonality and lack of quality legal privileges for building and using an eco-friendly infrastructure have a strong influence on the total number of certified hotels, which is quite small. The Association of Employers in Croatian Hospitality awarded 21 Croatian hotels with the label "Sustainable hotel", in basic, superior and advance category (Association of Employers in Croatian Hospitality, 2017). Each of the awarded hotels achieves great results in energy efficiency, waste recycling and adequate disposal, reduction of $\mathrm{CO} 2$ and GHG emissions, etc. Still, Croatia is not promoted or globally recognized as a sustainable or "green" destination and all the efforts of individual companies are important, but they unfortunately still do not have synergy.

An example of a large tourism company with strong environmental and social responsibility is Valamar Riviera as the leading tourism group in Croatia, encompassing 10 percent of the country's categorized accommodation capacity (Valamar Riviera, 2018a). Valamar Riviera developed 9 umbrella programs of corporate social responsibility oriented towards employee development and training, destination development, investments in the local community, helping those in need, preserving the environment, etc. In 2016, Valamar Riviera invested around 6600000 EUR, which is around $3.37 \%$ of the company's total revenue, on programs listed in table 2 (Valamar Riviera, 2018b).

Table 2 CSR programmes of Valamar Riviera

\begin{tabular}{|c|c|}
\hline $\begin{array}{l}\text { Enriching } \\
\text { the } \\
\text { Destination }\end{array}$ & $\begin{array}{l}\text { Support to cultural, culinary, educational } \\
\text { and entertainment events, projects } \\
\text { and initiatives that improve the attractiveness } \\
\text { and competitiveness of a destination and } \\
\text { cultivate the local cultural identity and values. }\end{array}$ \\
\hline $\begin{array}{l}\text { Building } \\
\text { Tourism } \\
\text { Infrastruc- } \\
\text { ture }\end{array}$ & $\begin{array}{l}\text { Systematic investments in beaches, walking } \\
\text { and biking trails, access paths, playgrounds } \\
\text { and other forms of improvement to the tour- } \\
\text { ism infrastructure. }\end{array}$ \\
\hline $\begin{array}{l}\text { Excellence } \\
\text { Through } \\
\text { Knowledge }\end{array}$ & $\begin{array}{l}\text { Project carried out in } 2016 \text { in cooperation with } \\
\text { the Ministry of Tourism, awarding } \\
198 \text { scholarships for students pursuing } \\
\text { careers in tourism and catering across } \\
\text { Croatia. Valamar also provided those stu- } \\
\text { dents with internships and employment once } \\
\text { their education was completed. }\end{array}$ \\
\hline ValamART & $\begin{array}{l}\text { Supporting the creativity of national and } \\
\text { foreign artists. }\end{array}$ \\
\hline $\begin{array}{l}\text { Promoting } \\
\text { Sports }\end{array}$ & $\begin{array}{l}\text { Organisation and/or sponsorship of a number } \\
\text { of sports events in all of Valamar's } \\
\text { destinations. Most of the sports events are } \\
\text { held in both pre-season and post-season, } \\
\text { with an exceedingly positive effect on guest } \\
\text { arrivals outside peak season. }\end{array}$ \\
\hline $\begin{array}{l}\text { Green } \\
\text { Valamar }\end{array}$ & $\begin{array}{l}\text { Energy efficiency projects and various } \\
\text { environmental protection initiatives, in the } \\
\text { context of everyday operations and } \\
\text { awareness-raising activities among } \\
\text { guests, employees and the local community } \\
\text { about the importance of preserving the } \\
\text { Adriatic coast and sea. }\end{array}$ \\
\hline $\begin{array}{l}\text { Our Retired } \\
\text { Colleagues }\end{array}$ & $\begin{array}{l}\text { Fostering long-term relations with retired } \\
\text { employees, primarily as a gesture of } \\
\text { gratitude, but also with the intent to include } \\
\text { former colleagues and exchange experiences } \\
\text { that could contribute to Valamar's growth and } \\
\text { development. }\end{array}$ \\
\hline $\begin{array}{l}\text { Little } \\
\text { Tourism }\end{array}$ & $\begin{array}{l}\text { Organised visits to hotels by kindergar- } \\
\text { ten groups from Valamar's destinations, so } \\
\text { that the children could learn their first facts } \\
\text { about vocations in the hospitality industry, but } \\
\text { in a playful and entertaining way. }\end{array}$ \\
\hline $\begin{array}{l}\text { Valamar's } \\
\text { Big Heart }\end{array}$ & $\begin{array}{l}\text { A framework for fundraisers, charity } \\
\text { initiatives and projects intended to help } \\
\text { those in need. }\end{array}$ \\
\hline
\end{tabular}

Source: Adapted from Valamar Riviera, 2018b

Without any intention to undermine the importance of the efforts of Valamar Riviera in the field of corporate social responsibility, and the positive impact they have on environment and society, it is 
important to emphasize that most of the programs listed in the Table 2, apart from social/environmental sustainability, also ensure additional benefits to Valamar as a provider of tourist offer. For example, supporting the construction of additional tourism infrastructure and organization of cultural and sport events results in a broader tourist offer and better experience for tourists and visitors. Scholarships for students, education on the hospitality industry for children, along with the program "Our retired colleagues", are well developed tools for ensuring a future workforce as well as the exchange of best practices between experienced workers and young employees with more theoretical knowledge.

\section{Conclusions}

The results of the discussion on hybrid spectrum typology applied to tourism reveal significant potential for developing socially and environmentally conscious organizations with strong economic sustainability. Unique examples from the Croatian tourism sector underlines the necessity of introducing more sustainable business models in this financially lucrative economic sector. Some of the examples reveal the complex nature of hybridization and underline the essential importance of specific context, legal framework and unique opportunities that affect making decisions on strategic organizational choices and defining the hybrid nature itself. Achieving synergy between economic and social goals by transferring economic benefits achieved through a tourismoriented offer to social missions is a challenging strategic task. Hybrid spectrum typology can help shed more light on categorizing organizations according to their mission and profit status, but apart from the theoretical framework, more research is needed on the hybridization process in practice in modern organizations.

The discussion on the implementation and issues surrounding hybrid organizations is important in terms of practitioners as well as academia. The strategic implications of choosing to mix social and economic goals are broad and it is important to understand the crucial role of legal and institutional contexts. Even though it was not designed to be quantitative empirical research with rigorous methodology and a carefully selected representative sample, this paper offered some important insights and indicated a potential for future research. Conclusions are in favor of developing hybrid organizations in the tourism sector, but, similar to other types of economic activi- ty: mission-driven hybrid organizations struggle with financial self-sustainability while profitdriven organizations rarely exhibit activities that are not at the same time useful in raising their financial figures. The role of the specific contexts of national legislation and favorable opportunities can determine whether hybrid organization shall succeed or fail, but also decide if an organization is a true hybrid by choice, or hybrid by chance, due to other factors.

\section{Acknowledgements}

This paper has been financially supported by University of Rijeka, for the project ZP UNIRI 6/16.sm

\section{References}

Alberti, F.G., \& Varon Garrido, M.A. (2017). Can profit and sustainability goals co-exist? New business models for hybrid firms. Journal of Business Strategy, 38 (1), 3-13. doi: 10.1108/JBS-12-2015-0124.

Alter K. (Ed.). (2007). Social Enterprise Typology. Wilmington: Virtue Ventures LLC.

Association of Employers in Croatian Hospitality (2017), Projekt „Zeleno poslovanje u hotelijerstvu“ udruge poslodavaca $u$ hotelijerstvu Hrvatske. Retreived April 12, 2018, from http://www.upuhh.hr/en/projekti/greensustainable-business/sustainable-hotels/item/27projekt-zeleno-poslovanje-u-hotelijerstvu-udrugeposlodavaca-u-hotelijerstvu-hrvatske.

Battilana, J., Lee, M., Walker, J. \& Dorsey, C. (2012). In search of the hybrid ideal. Stanford Social Innovation Review, 10 (3), 51-55.

Financial Agency (FINA). (2018). Annual Financial Reports Registry. Retrieved May 19, 2018, from http://rgfi.fina.hr/JavnaObjava-web/prijava.do

Ostroff, F.,\&Smith, D.(1992). tehe horizontal organization Tho McKinsey Quartorly, 1 (1), 148-167. doi: 10.1016/ijsm.2006.01.003.

Cooney, K. (2006). The institutional and technical structuring of nonprofit ventures: case study of a US hybrid organisation caught between two fields. Voluntas, 17 (2), 137-161.

Croatian Bureau of Statistics (2011). Census of Population, Households and Dwellings 2011, Retreived May 18, 2018, from

https://www.dzs.hr/eng/censuses/census2011/censuslo go.html

Croatian Bureau of Statistics (2018, February 13). First release. Retreived April 29, 2018, from http://www.mint.hr/UserDocsImages//AA_2018_cdokumenti//180213_DZS_2017.pdf

Croatian National Tourist Board (2018). Tourist Board Offices. Retrieved May 5, 2018, from https://www.htz.hr/hr-HR/opce-informacije/tz-uredi

Croatian Parliament (2014). Law on Associations. Official Gazette of the Republic of Croatia, No. 88/14. Retreived May 8, 2018, from https://udruge.gov.hr/UserDocslmages/dokumenti/Law \%20on\%20Associations_\%202014_ENG.pdf 
Croatian Parliament (2008). Law on Tourism Boards, Official Gazzette of the Republic of Croatia, No 152/08. Retreived May 12, 2018, from https://www.zakon.hr/z/342/Zakon-oturisti\%C4\%8Dkim-zajednicama-i-promicanjuhrvatskog-turizma

Dees, G. J. (1998). Enterprising nonprofits. Harvard Business Review, 76 (1), 54-67.

Dees, G.J. \& Anderson, B.B. (2003). Sector-bending: blurring lines between nonprofit and for-profit. Society, 40 (4), 16-27.

Defourny, J., Nyssens, M. (2013). Social Co-Operatives: When Social Enterprises meet the Co-Operative Tradition. Journal of Entrepreneurial and Organizational Diversity, 2 (2), 11-33.

Dwyer L., Ateljević I., \& Tomljenović, R. (2017). Tourism Future: Towards Transformational Tourism. In: Dwyer L., Tomljenović R., Čorak S. (Eds.), Evolution of Destination Planning and Strategy (pp. 279-294). Cham: Palgrave Macmillan.

Đurkin, J.\& Wise, N. (2017). Managing community stakeholders in rural areas: Assessing the organisation of local sports events in Gorski kotar, Croatia. In Jepson, A. \& Clarke, A. (Eds.), Power, Construction and Meaning in Festivals (pp. 185-201). Oxon: Routledge.

Society of Friends of Dubrovnik Antiques (2017). Financial report of Society of Friends of Dubrovnik Antiques for 2016. Retrieved May 10, 2018, from http://citywallsdubrovnik.hr/wpcontent/uploads/2017/12/Financijski-za-2016.pdf

Gavrilović, Z. \& Maksimović, M. (2018). Green Innovations in the Tourism Sector. Strategic ManagementInternational Journal of Strategic Management and Decision Support Systems in Strategic Management, 23 (1), 36-42.

Government of the Republic of Croatia (2015). Strategy for the Development of Social Entrepreneurship in the Republic of Croatia 2015-2020. Retreived April 27, 2018, from

https://vlada.gov.hr/UserDocs/mages/Sjednice/2015/22 $6 \% 20$ sjednica\%20Vlade/226\%20-\%207.pdf

Grassl, W. (2012). Business Models of Social Enterprise: A Design Approach to Hybridity. ACRN Journal of Entrepreneurship Perspectives, 1 (1), 37-60.

Haigh, N. \& Hoffman, A.J. (2012). Hybrid organizations: the next chapter of sustainable business. Organizational Dynamics, 41 (2), 126-134.

Hedona (2018). Hedona Ltd Chocolaterie - social enterprise from Križevci Croatia. Retrieved May 27, 2018, from http://hedona.hr/?lang=en

Institute for Tourism (2013). Tourism Development Strategy of the Republic of Croatia until 2020. Retrieved April 2, 2018, from http://www.mint.hr/strategija-razvojaturizma-11411/11411.

Istra Inspirit Association (2018). Istra Inspirit Events. Retrieved May 20, 2018, from http://istrainspirit.hr/dozivljaji/.

Mair, J. \& Marti, I. (2006). Social entrepreneurship research: a source of explanation, prediction and delight. Journal of World Business, 45 (1), 36-44.
Mandić, A., Mrnjavac, Ž. \& Kordić, L. (2018). Tourism infrastructure, recreational facilities and tourism development. Tourism and Hospitality Management, 24 (1), 41-62.

Ministry of Public Administration (2018). Register of Associations of the Republic of Croatia. Retreived April 12, 2018, from https://registri.uprava.hr/\#!udruge/

Minnaert, L., Maitland, R. \& Miller, G. (2011). What is social tourism?. Current Issues in Tourism, 14 (5), 403-415.

Mon Perin (2018a). What is Mon Perin?. Retrieved April 15, 2018, from https://www.campingmonperin.hr/blog/detailed/what-is-mon-perin.

Mon Perin (2018b). Trgovačko društvo "Mon Perin" d.o.o. Retreived April 18, 2018, from http://www.monperin.hr/monperin-izvjesca.html

Perić, M. \& Đurkin, J. (2014). Systems thinking and alternative business model for responsible tourist destination. Kybernetes, 43 (3/4), 480- 496.

Perić, M., Đurkin, J., \& Lamot, I. (2014). Importance of stakeholder management in tourism projects: Case study of Istria Inspirit project. In Perić, J. (Ed.), 22nd Biennial International Congress Tourism and Hospitality Industry 2014: Trends in Tourism and Hospitality Management Congress Proceedings (pp. 273-286). Opatija: University of Rijeka Faculty of Tourism and Hospitality Management.

Schmitz, B., \& Glänzel, G. (2016). Hybrid organizations: concept and measurement. International Journal of Organizational Analysis, 24 (1), 18-35.

Slivar, I., \& Golja, T. (2015). Boosting Corporate Social Responsibility in tourist destinations through loyalty programs and stakeholder collaboration. Journal of Economics and Behavioral Studies, 7 (4), 122-133.

Šimleša, D., Bušljeta Tonković, A., \& Puđak, J. (2016). Društveno poduzetništvo u Hrvatskoj: od prepoznavanja do primjene. Revija za sociologiju, 46 (3), 271-295.

UNWTO (2018, January 15). 2017 International Tourism Results: the highest in seven years. Retrieved March 27, 2018, from http://media.unwto.org/pressrelease/2018-01-15/2017-international-tourism-resultshighest-seven-years

Valamar Riviera (2018a). Valamar Group. Retreived May 5 , 2018, from https://www.valamar.com/en/valamar-group

Valamar Riviera (2018b). CSR Programs. Retreived May 5, 2018, from https://valamar-riviera.com/en/socialresponsibility/csr-programs/\#image-0

Vidović, D., \& Rakin, D. (2017). Social Entrepreneurship and the Revitalization of the Cooperative sector: Emergence of Social Cooperatives in Croatia and Serbia. In Baglioni, S., Roy, M., Mazzei, M., Srbijanko, J.K. \& Bahevska, M. (Eds.) Social Enterprise Developments in the Balkans (pp. 7-22). Skopje: Reactor - Research in Action. 


\section{$\triangle$ Correspondence}

\section{Jelena Đurkin Badurina}

University of Rijeka, Faculty of Tourism and Hospitality Management

Primorska 42, p.b. 97, 51410 Opatija, Croatia

E-mail: jelenad@fthm.hr 